S. Tantanee et al.

\section{Downscaled Rainfall Prediction Model (DRPM) using a Unit Disaggregation Curve (UDC)}

Title Page

Abstract Introduction

Conclusions References

Tables Figures

S. Tantanee ${ }^{1}$, S. Patamatamakul ${ }^{2}$, T. Oki $^{3}$, V. Sriboonlue ${ }^{2}$, and T. Prempree ${ }^{2}$

${ }^{1}$ Graduate School, Khon Kaen University, Muang, Khonkaen, Thailand

${ }^{2}$ Engineering Faculty, Khon Kaen University, Muang, Khonkaen, Thailand

${ }^{3}$ Institute of Industrial Science, University of Tokyo, Tokyo, Japan

Received: 9 March 2005 - Accepted: 22 March 2005 - Published: 14 April 2005

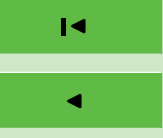

1

Back

Close

Full Screen / Esc

Correspondence to: S. Tantanee (stantanee@yahoo.com)

(C) 2005 Author(s). This work is licensed under a Creative Commons License.
Print Version

Interactive Discussion 


\section{Abstract}

This study was undertaken to identify the process for generating finer time scaled rainfall from higher time scaled data. The Downscaled Rainfall Prediction Model (DRPM) using the technique of unit disaggregation curve (UDC) was developed under the con5 cept of coupling the stochastic autoregressive (AR) model with a wavelet filter and disaggregation model. Sequences of the number of rainy days and monthly rainfall were simulated from 52-year rainfall records at 4 stations in the northeastern part of Thailand. Compared with actual rainfall sequences, the 30 year generated sequences provided R-square values of $0.47-0.60$. The model was applied to forecast the num-

\section{Introduction}

Various hydrological models need the predicted rainfall series to simulate the water resources system for future planning. Rainfall series are the hydrological time series composed of deterministic and stochastic components. In order to consider the deterministic part, the nuances of the series, which is noise of signal, have to be eliminated. The deterministic part can describe the mathematical characteristics of the series. The dependency of stochastic components of the series can be analyzed using the autoregressive (AR) model which is the model applied for analyzing the rainfall series (Thomas and Fiering, 1962; Yevjevich, 1963; Box and Jenkins, 1970). Normally, the hydrological process is studied in different time scales. Several disaggregation models have been developed for numerous hydrological applications (Valencia and Shaake, 1973; Mejia and Rousselle, 1976; Hoshi and Burgs, 1979; Stedinger and Vogel, 1984; Koutsoyiannis, 1992). In recent years, the wavelet transform has been successfully applied to wave data analysis and other ocean engineering applications (e.g. Lau and Weng, 1995; Massel, 2001; Teisseire et al., 2002; Huang, 2004). The objective of this 
study is to develop the process for rainfall prediction by coupling a wavelet filter with AR and the disaggregation concept. The unit disaggregation curve (UDC) technique was also developed in order to describe the pattern of rainfall distribution within a year. The proposed model is the downscaled prediction model of annual to monthly series, which 5 is the time scale required in the simulation model for the purpose of water resources planning and management.

\section{Data input}

The point rainfall data for the 1951-2002 records from 4 gauging stations distributed over the northeastern part of Thailand were analyzed using the Downscaled Rainfall

10 Prediction Model (DRPM). The selected rainfall stations are part of the Thai Meteorological Department (TMD). Details are shown in Fig. 1 and Table 1.

\section{Applied theory and model structure}

The basic process of the model developed is the coupling of a wavelet filter with the AR model. The process is divided into 2 steps: the annual prediction step and the downscaling step. In the downscaling step, a unit disaggregation curve (UDC) was constructed to demonstrate the pattern of rainfall distribution. This unit curve can be applied to annual data to generate the monthly data.

3.1. Coupling of the autoregressive model with a wavelet filter

Generally, a signal or function $f(t)$ can be expressed in linear decomposition (Burrus et al., 1998) by

$f(t)=\sum_{\ell} a_{\ell} \psi_{\ell}(t)$,

DRPM using a UDC

S. Tantanee et al.

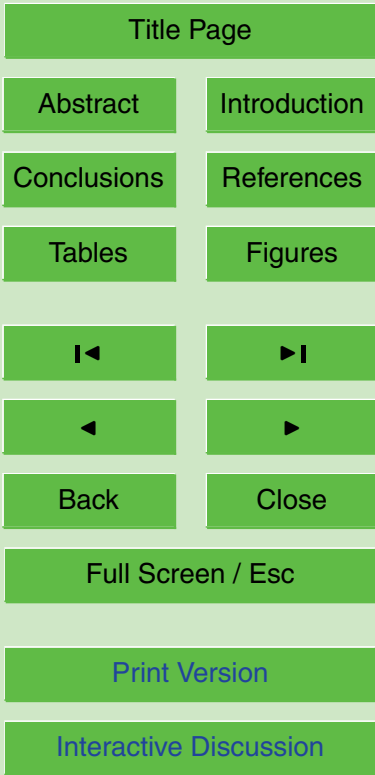

EGU 
where $\ell$ is an integer index for the finite $\operatorname{sum}(\ell=1,2, \ldots, \ell)$ or infinite sum $(\ell=1,2, \ldots$, $\infty) . a_{\ell}$ are the real valued expansion coefficients, and $\psi_{\ell}(t)$ are the set of real valued functions of $t$ called the expansion set. For the wavelet a two parameter system is constructed and the Eq. (1) becomes

$f(t)=\sum_{k} \sum_{j} a_{j, k} \psi_{j, k}(t)$

where $j$ and $k$ are integer indices and the $\psi_{j, k}(t)$ are the basis expansion functions of the mother wave $\psi(t)$. The set of expansion coefficients $a_{j, k}$ is called a discrete wavelet transform (DWT) of $f(t)$ and Eq. (2) is the inverse transform. A wavelet system is a two-dimensional expansion set (basis) for some class of one-dimensional signal. The wavelet expansion provides a time-frequency localization of the signal. Firstgeneration wavelet systems are generated from a single scaling function (wavelet) by simple scaling and translation. The two dimensional parameterization is achieved from the function (mother wave) $\psi(t)$ by

$\psi_{j, k}(t)=2^{j / 2} \psi\left(2^{j} t-k\right)$,

15 where the factor $2^{j / 2}$ maintains a constant norm independence of scale $j$. This parameterization of the time or space location by $k$ and the frequency or the logarithm of scale by $j$ turns out to be effective.

In order to generate a set of expansion functions, the signal can be represented by the series

$f(t)=\sum_{j, k} a_{j, k} 2^{j / 2} \psi\left(2^{j} t-k\right)$.

An efficient way to implement DWT is to use a filter process. Normally, the lowfrequency content of the signal (approximations, A) is the most important part. It demonstrates the signal identity. The high-frequency component (detail, $D$ ) is nuance. The original signal, S, passes through two complementary filters and emerges as two

DRPM using a UDC

S. Tantanee et al.

Title Page

Abstract Introduction

Conclusions References

Tables Figures
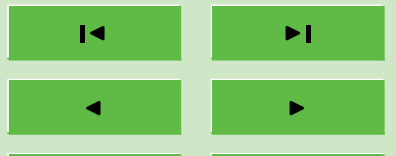

Back

Close

Full Screen / Esc

Print Version

Interactive Discussion 
signals of $A$ and $D$. Figure 2 shows the rainfall series with a 1-3 layer filter where $A$ and $D$ are separated. By applying the historical rainfall sequences with this filter, both the $A$ and $D$ series was analyzed separately with $A R$ for the step of annual rainfall prediction.

The autoregressive (AR) model has been extensively applied to hydrology and water 5 resources analysis. The AR is intuitive time dependent model, where the value of a variable at the present time depends on the values at the previous time. AR models may have constant parameters, parameters varying with time or a combination of both. For AR with constant parameters, a stationary time series $y t$ normally distributed with mean $\mu$ and variance $\sigma^{2}$, the AR of order $p$, denoted by AR $(p)$, can be represented 10 as:

$y_{t}=\mu+\phi_{1}\left(y_{t-1}-\mu\right)+\ldots .+\phi_{p}\left(y_{t-p}-\mu\right)+\varepsilon_{t}$

$y_{t}=\mu+\sum_{j=1}^{p} \phi_{j}\left(y_{t-j}-\mu\right)+\varepsilon_{t}$,

where $y t$ is the time dependent series and $\varepsilon_{t}$ is the time independent series which is uncorrelated with $y t$. The series of $y t$ is also normally distributed with the mean zero 15 and variance $\sigma_{\varepsilon}^{2}$. The coefficients $\phi_{1}, \ldots, \phi_{p}$ are called autoregressive coefficients. Various forms of AR models, which have been used in the field of stochastic hydrology, represent the same autoregressive process. (Fiercing and Jackson, 1971; Yevjevich, 1972; Box and Jenkins, 1972) In order to yield a normal series, it is necessary to transform the series before carrying out the analysis. Instead of the conventional transformation of logarithm transform or $z$ transform, the wavelet filter was coupled with the AR model in this study.

The process for annual rainfall prediction is shown in Fig. 3. The fourth order of $A R$ was used to generate both the $A$ and $D$ series and the predicted annual rainfall obtained from reconstruction from these generated series.

25 The R-square $\left(R^{2}\right)$ and mean square error (MSE) obtained from the simulation of the annual rainfall series using AR with a 1-3 layer filter is shown in Tables 2 and 3 for the 
number of rainy days per year and the annual rainfall, respectively.

With the high level of R-square in all levels of wavelet filter used, it can be stated that the process is able to describe the annual series of rainfall characteristics. Therefore, further study was conducted to analyze the pattern of rainfall distribution over a year in 5 order to develop the process of downscaled rainfall prediction.

\subsection{Unit Disaggregation Curve (UDC)}

The basic concept of disaggregation in terms of a linear dependence model (Valencia and Schaake, 1973) can easily be expressed as:

$Y=A X+B \underline{\varepsilon}$,

10 where $Y$ is the current observation of the series being generated (subseries or monthly series in this study) and depends on the current values of the $X$ series (key series or annual series); $A$ and $B$ are the parameters; and $\varepsilon$ represents the stochastic term. A study was carried out under the concept of the linear relationship between annual and monthly series. The distribution of rainfall over a year was obtained from analyzing the historical monthly rainfall series. As the monthly series of rainfall is also a time series composed of deterministic and stochastic components, the series was applied freshly through a wavelet filter in order to separate the Approximation (A) and Details (D). Then, both A and D were analyzed using the AR model. A demonstrates the signal characteristic, whereas $D$ is the nuance of the signal. Therefore, the pattern of monthly rainfall distribution is obtained from $A$. Figure 4 shows the distribution of $A$ for number of rainy days and rainfall within a year obtained from 52 year records of rainfall. The figure illustrates that the signal identity disappeared when passing through a 3 layer wavelet filter. With the polynomial fitting and mean value curve, the distribution curve of Approximations was obtained.

25 The unit disaggregation curve is constructed from the cumulative value of the distribution curve of Approximations and alters to a unit curve. Figure 5 shows the UDC for the number of rainy days and the rainfall of the Ubon Ratchathani station. The obtained

\section{HESSD}

2, 543-568, 2005

DRPM using a UDC

S. Tantanee et al.

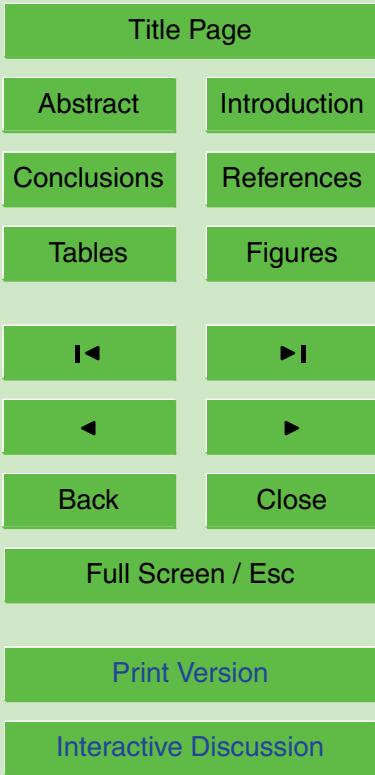

EGU 
UDC was applied directly to the predicted annual rainfall to generate monthly rainfall. The process of monthly rainfall prediction is shown in Fig. 6 . The process is similar to the annual rainfall prediction when $A$ and $D$ are generated separately. For the monthly rainfall prediction, $D$ of the annual series is considered in detail. The reconstruction 5 process of the monthly signal is done by merging the generated $A$ with generated $D$; therefore, the $D$ or nuance already existed in the generated series. That is why the $D$ of the annual rainfall has to be eliminated before conducting the downscaled process to predict the monthly rainfall.

\section{Result and discussion}

10 The simulation was undertaken using the 52 year historical data of the number of rainy days and rainfall. Tables 4 and 5 show the obtained R-square of the 30 year (19732002) generated series compared with the historical data of number of rainy days and monthly rainfall, respectively. Figures 7 and 8 demonstrate the example graphs of the 1997-2002 generated series from the DRPM of a 1-3 level filter for the number of rainy days and monthly rainfall, respectively. With high R-square values of 0.760 0.855, the DRPM with a 2 level wavelet filter and UDC from both a polynomial curve and a mean value curve are appropriate to describe the characteristics of number of rainy day series. In case of the rainfall series simulation, the DRPM with a 2 level wavelet filter and UDC from both polynomials and mean values provide the R-square values of $0.469-0.605$ which can be used to describe the pattern of rainfall series, as well.

Further study was carried out to utilize DRPM as the rainfall prediction for the year 2002 compared with the records. Tables 6 and 7 show the obtained R-square for predicted rainfall and historical data. Figures 9 and 10 illustrate the distribution pattern for predicted values compared with the records in year 2002. It can be seen that the DRPM with a 2 level wavelet filter is the most appropriate process for the rainfall prediction model.

\section{HESSD}

2, 543-568, 2005

DRPM using a UDC

S. Tantanee et al.

\section{Title Page}

\section{Abstract} Introduction

Conclusions References

Tables Figures

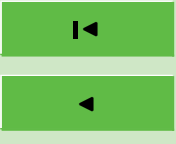
$\rightarrow$

Back

Close

\section{Full Screen / Esc}

Print Version

Interactive Discussion

EGU 


\section{Conclusions}

DRPM is a multi-step prediction model, developed from coupling the AR model with a wavelet filter. The construction of UDC is to study the pattern of rainfall distribution within a year to apply for downscaling rainfall from the large time scale to a finer scale.

5 Although, the DRPM can be applied for both the number of rainy days per month and monthly rainfall, the DRPM provides a better result when applied to the number of rainy days. However, the DRPM can be utilized for predicting annual and monthly rainfall reasonably well to serve the purpose of water resources planning.

\section{References}

Box, G. E. P. and Jenkins, G.: Time series analysis, forecasting and control, Holden-Day Inc., San Francisco, 1970.

Burrus, C. S., Gopinath, R. A., and Guo, H.: Introduction to wavelets and wavelet transforms, Prentice-Hall International Inc., Texas, 1998.

Carlson, R. F., MacCormick, A. J. A., and Watts, D. G.: Application of linear model to four annual stream flow series, J. Water Resour. Res., 6, 4, 1070-1078, 1970.

Feircing, M. B. and Jackson, B. B.: Synthetic hydrology monograph no. 1., American geophysicaal Union, Washington D.C., 1971.

Hoshi, K. and Burges, S. J.: Disaggregation of streamflow volumes, J. of Hydrology, Div., ASCE, 105, 27-41, 1979.

20 Huang, M.-C.: Wave parameters and functions in wavelet analysis, Ocean Engineering, 31, 1, 111-125, 2004.

Jury, M. R. and Melice J.-L.: Analysis of Durban rainfall and Nile river flow 1871-1999, Theor. Appl. Climatol., 67, 161-169, 2000.

Koutsoyiannis, D., A stochastic disaggregation method for design strom and flood synthesis, J. of Hydrology, 156, 193-225, 1994.

Koutsoyiannis, D.: Coupling stochastic models of different time scales, J. Water Resour. Res., 37, 2, 379-391, 2001.

\section{HESSD}

2, 543-568, 2005

DRPM using a UDC

S. Tantanee et al.

Title Page

Abstract

Introduction

Conclusions

References

Tables

Figures

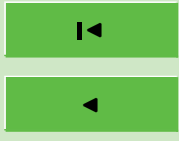

$\rightarrow$

Back

Close

\section{Full Screen / Esc}

Print Version

Interactive Discussion

EGU 
Lau, K. M. and Weng, H. Y.: Climate signal detection using wavelet transform: how to make a time series sing, Bull. Amer. Meteor Soc., 76, 2391-2402, 1995.

Mallat, S.: A wavelet tour of signal processing, San Diego, CA: Academic Press, 1998.

Matalas, N. C. and Willis, J. R.: Statistical properties of multivariate fractional noise processes,

$5 \quad$ J. Water Resour. Res., 7, 6, 1460-1468, 1971.

Massel, S. R.: Wavelet analysis for processing of ocean surface wave records, Ocean Engineering, 28, 957-987, 2001.

Mejia, J. M. and Rousselle, J.: Disaggregation models in hydrology revisited, J. Water Resour. Res., 12, 2, 185-186, 1976.

10 Salas, J. D. Delleur, J. W., Yevjevich, V., and Lane, W. L.: Applied modeling of hydrological time series, Book Crafters, Inc. Michigan, 1985.

Stedinger, J. R. and Vogel R. M.: Disaggregation procedures for generating serially corrected flow vector, J. Water Resour. Res., 20, 1, 47-56, 1984.

Teisseire, L. M., Delafoy, M. G., Jordan, D. A., Miksad, R. W., and Weggel, D. C.: Measurement 15 of the instantaneous characteristics of natural response modes of a spar platform subjected to irregular wave loading, International Journal of offshore and polar Enigineering, 12, 1, 16-24, 2002.

Thomas, H. A. and Fiering, M. B.: Mathematic synthesis of streamflow sequences for analysis of river basins by simulation. In Design of water resources systems, Mass, A. et al., 459-493, Harvard University press, Massachusetts, 1962.

Torrence, C. and Compo, G. P.: A practical guide to wavelet analysis, Bull. Amer. Meteor. Soc., 79, 1, 61-78, 1997.

Tsui, F.-C., Li, C. C., Sun, M. et al.,: A comparative study of two biorthogonal wavelet transforms in time series prediction, IEEE, 1997.

Valencia, D. R., and Schaake, J. C. Jr.: Disaggregation processes in stochastic hydrology, J. Water Resour. Res., 9, 3, 580-585, 1973.

Yevjevich, V.: Fluctuation of wet and dry years, Part 1 Hydrology paper 1, Colorado State University, Fort Collins, Colorado, 1963.

Yevjevich, V.: Stochastic processes in hydrology, Water Resources publication, Fort Collins, Colorado, 1972a.

Yevjevich, V.: Structural Analysis of hydrological time series, Hydrology paper, 56, Colorado State University, Fort Collins, Colorado, 1972b.

HESSD

2, 543-568, 2005

DRPM using a UDC

S. Tantanee et al.

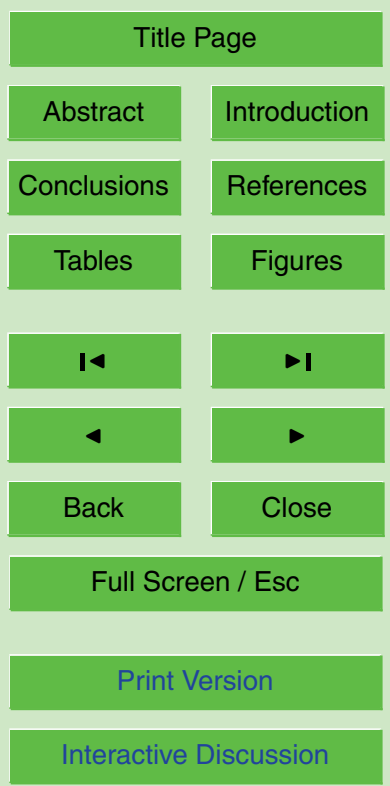

EGU 


\section{HESSD}

2, 543-568, 2005

\section{DRPM using a UDC}

S. Tantanee et al.

Table 1. Details of 4 selected rainfall stations.

\begin{tabular}{lclccc}
\hline \multicolumn{1}{c}{ Station } & $\begin{array}{c}\text { Period of } \\
\text { record }\end{array}$ & $\begin{array}{c}\text { Latitude }- \\
\text { longitude }\end{array}$ & $\begin{array}{c}\text { No. } \\
\text { Year } \\
\text { of } \\
\text { record }\end{array}$ & $\begin{array}{c}\text { Climatic } \\
\text { mean } \\
(\mathrm{mm})\end{array}$ & $\begin{array}{c}\text { Mean } \\
\text { number } \\
\text { of wet } \\
\text { days }\end{array}$ \\
\hline 381201 Khon Kaen & $1951-2002$ & $\begin{array}{l}16.26 \mathrm{~N} \\
102.50 \mathrm{E}\end{array}$ & 52 & 1212.5 & 87.21 \\
431201 Nakhon Ratchasima & $1951-2002$ & $\begin{array}{l}14.58 \mathrm{~N} \\
102.05 \mathrm{E}\end{array}$ & 52 & 1092.6 & 86.73 \\
407501 Ubon Ratchathani & $1951-2002$ & $\begin{array}{l}15.15 \mathrm{~N} \\
104.52 \mathrm{E}\end{array}$ & 52 & 1580.8 & 100.88 \\
354201 Udon Thani & $1951-2002$ & $\begin{array}{l}17.23 \mathrm{~N} \\
102.48 \mathrm{E}\end{array}$ & 52 & 1460.3 & 101.42 \\
\hline
\end{tabular}

Title Page

Abstract Introduction

Conclusions

Tables

References

Figures

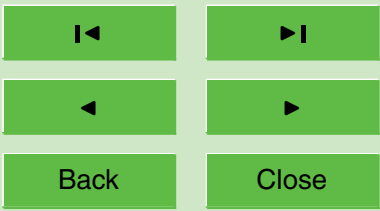

Full Screen / Esc

Print Version

Interactive Discussion 
2, 543-568, 2005

\section{DRPM using a UDC}

S. Tantanee et al.

Table 2. The simulation results of the number of rainy day per year.

\begin{tabular}{ccccccccc}
\hline Model & \multicolumn{2}{c}{ Udonthani } & \multicolumn{2}{c}{ Khom Kaen } & Nakhonratchasima & \multicolumn{2}{c}{ Ubonratchathani } \\
& & & & & & & & \\
& & & & & & & & \\
& & MSE & $\mathrm{R}^{2}$ & MSE & $\mathrm{R}^{2}$ & MSE & $\mathrm{R}^{2}$ & MSE \\
\hline AR - 1 level wavelet filter & 0.8983 & 22.6648 & 0.9322 & 5.8708 & 0.8874 & 21.0323 & 0.9294 & 8.7720 \\
AR - 2 level wavelet filter & 0.9646 & 7.8990 & 0.9615 & 3.3350 & 0.9346 & 12.2230 & 0.9626 & 4.6413 \\
AR - 3 level wavelet filter & 0.9693 & 6.8496 & 0.9670 & 2.8596 & 0.9398 & 11.2396 & 0.9684 & 3.9218 \\
\hline
\end{tabular}

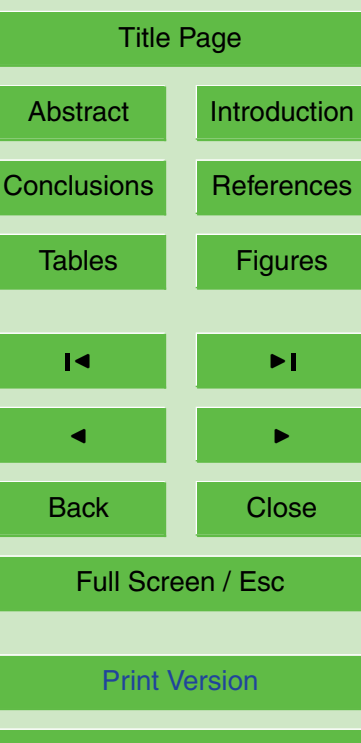

Interactive Discussion 
2, 543-568, 2005

\section{DRPM using a UDC}

S. Tantanee et al.

Table 3. The simulation result of the annual rainfall.

\begin{tabular}{|c|c|c|c|c|c|c|c|c|}
\hline \multirow{2}{*}{ Model } & \multicolumn{2}{|c|}{ Udonthani } & \multicolumn{2}{|c|}{ Khom Kaen } & \multicolumn{2}{|c|}{ Nakhonratchasima } & \multicolumn{2}{|c|}{ Ubonratchathani } \\
\hline & $\mathrm{R}^{2}$ & MSE & $\mathrm{R}^{2}$ & MSE & $\mathrm{R}^{2}$ & MSE & $\mathrm{R}^{2}$ & MSE \\
\hline AR - 1 level wavelet Filter & 0.8907 & 8538.1754 & 0.9228 & 5327.7085 & 0.8954 & 554.9483 & 0.9210 & 5317.6073 \\
\hline AR - 2 level wavelet filter & 0.9346 & 5110.6815 & 0.9568 & 2981.6889 & 0.9346 & 849.9213 & 0.9633 & 2466.7780 \\
\hline AR - 3 level wavelet filter & 0.9425 & 4496.4688 & 0.9603 & 2741.2951 & 0.9404 & 595.1318 & 0.9684 & 2126.6607 \\
\hline
\end{tabular}

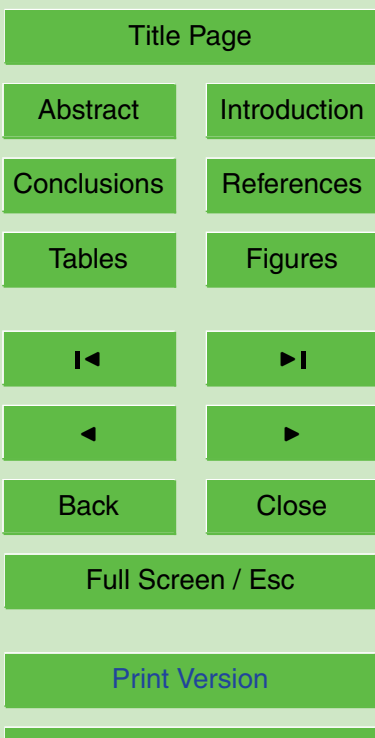

Interactive Discussion

EGU 


\section{DRPM using a UDC}

S. Tantanee et al.

Table 4. Obtained R-square of 30 year generated series of number of rainy days.

\begin{tabular}{|c|c|c|c|c|c|c|c|c|}
\hline \multirow[t]{3}{*}{ Model } & \multicolumn{2}{|c|}{ Udonthani } & \multicolumn{2}{|c|}{ Khom Kaen } & \multicolumn{2}{|c|}{ Nakhonratchasima } & \multicolumn{2}{|c|}{ Ubonratchathani } \\
\hline & \multicolumn{2}{|c|}{$\mathrm{R}^{2}$} & \multicolumn{2}{|l|}{$\mathrm{R}^{2}$} & \multicolumn{2}{|c|}{$\mathrm{R}^{2}$} & \multicolumn{2}{|c|}{$\mathrm{R}^{2}$} \\
\hline & $\begin{array}{l}\text { UDC from } \\
\text { Polynomial } \\
\text { curve }\end{array}$ & $\begin{array}{l}\text { UDC } \\
\text { from } \\
\text { Mean }\end{array}$ & $\begin{array}{l}\text { UDC from } \\
\text { Polynomial } \\
\text { curve }\end{array}$ & $\begin{array}{l}\text { UDC } \\
\text { from } \\
\text { Mean }\end{array}$ & $\begin{array}{l}\text { UDC from } \\
\text { Polynomial } \\
\text { curve }\end{array}$ & $\begin{array}{l}\text { UDC } \\
\text { from } \\
\text { Mean }\end{array}$ & $\begin{array}{l}\text { UDC from } \\
\text { Polynomial } \\
\text { curve }\end{array}$ & $\begin{array}{l}\text { UDC } \\
\text { from } \\
\text { Mean }\end{array}$ \\
\hline $\begin{array}{l}\text { DRPM - } 1 \text { level } \\
\text { wavelet filter }\end{array}$ & 0.846 & 0.825 & 0.740 & 0.738 & 0.740 & 0.748 & 0.838 & 0.833 \\
\hline $\begin{array}{l}\text { DRPM - } 2 \text { level } \\
\text { wavelet filter }\end{array}$ & 0.847 & 0.835 & 0.764 & 0.765 & 0.778 & 0.760 & 0.846 & 0.855 \\
\hline $\begin{array}{l}\text { DRPM - } 3 \text { level } \\
\text { wavelet filter }\end{array}$ & 0.829 & 0.818 & 0.740 & 0.745 & 0.632 & 0.628 & 0.796 & 0.801 \\
\hline
\end{tabular}

Title Page

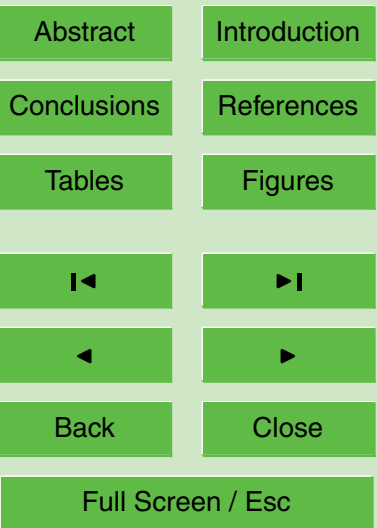

Print Version

Interactive Discussion 
2, 543-568, 2005

\section{DRPM using a UDC}

S. Tantanee et al.

Table 5. Obtained R-square of 30 year generated series of monthly rainfall.

Model

Udonthani

Khom Kaen

Nakhonratchasima

Ubonratchathani

\begin{tabular}{|c|c|c|c|c|c|c|c|c|}
\hline & \multicolumn{2}{|c|}{$\mathrm{R}^{2}$} & \multicolumn{2}{|c|}{$\mathrm{R}^{2}$} & \multicolumn{2}{|c|}{$\mathrm{R}^{2}$} & \multicolumn{2}{|c|}{$\mathrm{R}^{2}$} \\
\hline & $\begin{array}{l}\text { UDC from } \\
\text { Polynomial } \\
\text { curve }\end{array}$ & $\begin{array}{l}\text { UDC } \\
\text { from } \\
\text { Mean }\end{array}$ & $\begin{array}{l}\text { UDC from } \\
\text { Polynomial } \\
\text { curve }\end{array}$ & $\begin{array}{l}\text { UDC } \\
\text { from } \\
\text { Mean }\end{array}$ & $\begin{array}{l}\text { UDC from } \\
\text { Polynomial } \\
\text { curve }\end{array}$ & $\begin{array}{l}\text { UDC } \\
\text { from } \\
\text { Mean }\end{array}$ & $\begin{array}{l}\text { UDC from } \\
\text { Polynomial } \\
\text { curve }\end{array}$ & $\begin{array}{l}\text { UDC } \\
\text { from } \\
\text { Mean }\end{array}$ \\
\hline $\begin{array}{l}\text { DRPM -1 level } \\
\text { wavelet Filter }\end{array}$ & 0.558 & 0.514 & 0.314 & 0.300 & 0.449 & 0.497 & 0.599 & 0.591 \\
\hline $\begin{array}{l}\text { DRPM - } 2 \text { level } \\
\text { wavelet filter }\end{array}$ & 0.605 & 0.581 & 0.480 & 0.469 & 0.580 & 0.577 & 0.590 & 0.596 \\
\hline $\begin{array}{l}\text { DRPM - } 3 \text { level } \\
\text { wavelet filter }\end{array}$ & 0.594 & 0.589 & 0.440 & 0.430 & 0.373 & 0.373 & 0.584 & 0.585 \\
\hline
\end{tabular}




\section{DRPM using a UDC}

S. Tantanee et al.

Table 6. Obtained R-square of 2002 predicted Number of rainy days.

\begin{tabular}{|c|c|c|c|c|c|c|c|c|}
\hline \multirow[t]{3}{*}{ Model } & \multicolumn{2}{|c|}{ Udonthani } & \multicolumn{2}{|c|}{ Khom Kaen } & \multicolumn{2}{|c|}{ Nakhonratchasima } & \multicolumn{2}{|c|}{ Ubonratchathani } \\
\hline & \multicolumn{2}{|c|}{$\mathrm{R}^{2}$} & \multicolumn{2}{|l|}{$\mathrm{R}^{2}$} & \multicolumn{2}{|c|}{$\mathrm{R}^{2}$} & \multicolumn{2}{|c|}{$\mathrm{R}^{2}$} \\
\hline & $\begin{array}{l}\text { UDC from } \\
\text { Polynomial } \\
\text { curve }\end{array}$ & $\begin{array}{l}\text { UDC } \\
\text { from } \\
\text { Mean }\end{array}$ & $\begin{array}{l}\text { UDC from } \\
\text { Polynomial } \\
\text { curve }\end{array}$ & $\begin{array}{l}\text { UDC } \\
\text { from } \\
\text { Mean }\end{array}$ & $\begin{array}{l}\text { UDC from } \\
\text { Polynomial } \\
\text { curve }\end{array}$ & $\begin{array}{l}\text { UDC } \\
\text { from } \\
\text { Mean }\end{array}$ & $\begin{array}{l}\text { UDC from } \\
\text { Polynomial } \\
\text { curve }\end{array}$ & $\begin{array}{l}\text { UDC } \\
\text { from } \\
\text { Mean }\end{array}$ \\
\hline $\begin{array}{l}\text { DRPM -1 level } \\
\text { wavelet Filter }\end{array}$ & 0.840 & 0.851 & 0.657 & 0.762 & 0.589 & 0.666 & 0.840 & 0.851 \\
\hline $\begin{array}{l}\text { DRPM - } 2 \text { level } \\
\text { wavelet filter }\end{array}$ & 0.901 & 0.913 & 0.674 & 0.709 & 0.715 & 0.727 & 0.901 & 0.913 \\
\hline $\begin{array}{l}\text { DRPM - } 3 \text { level } \\
\text { wavelet filter }\end{array}$ & 0.884 & 0.888 & 0.327 & 0.376 & 0.640 & 0.649 & 0.884 & 0.888 \\
\hline
\end{tabular}

Title Page

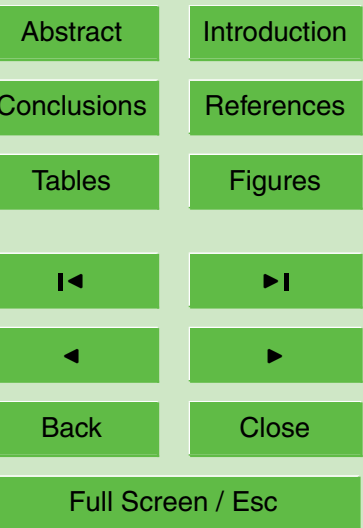

Print Version

Interactive Discussion 
2, 543-568, 2005

\section{DRPM using a UDC}

S. Tantanee et al.

Table 7. Obtained R-square of 2002 predicted monthly rainfall.

\begin{tabular}{|c|c|c|c|c|c|c|c|c|}
\hline \multirow[t]{3}{*}{ Model } & \multicolumn{2}{|c|}{ Udonthani } & \multicolumn{2}{|c|}{ Khom Kaen } & \multicolumn{2}{|c|}{ Nakhonratchasima } & \multicolumn{2}{|c|}{ Ubonratchathani } \\
\hline & \multicolumn{2}{|c|}{$\mathrm{R}^{2}$} & \multicolumn{2}{|c|}{$\mathrm{R}^{2}$} & \multicolumn{2}{|c|}{$\mathrm{R}^{2}$} & \multicolumn{2}{|c|}{$\mathrm{R}^{2}$} \\
\hline & $\begin{array}{l}\text { UDC from } \\
\text { Polynomial } \\
\text { curve }\end{array}$ & $\begin{array}{l}\text { UDC } \\
\text { from } \\
\text { Mean }\end{array}$ & $\begin{array}{l}\text { UDC from } \\
\text { Polynomial } \\
\text { curve }\end{array}$ & $\begin{array}{l}\text { UDC } \\
\text { from } \\
\text { Mean }\end{array}$ & $\begin{array}{l}\text { UDC from } \\
\text { Polynomial } \\
\text { curve }\end{array}$ & $\begin{array}{l}\text { UDC } \\
\text { from } \\
\text { Mean }\end{array}$ & $\begin{array}{c}\text { UDC from } \\
\text { Polynomial } \\
\text { curve }\end{array}$ & $\begin{array}{l}\text { UDC } \\
\text { from } \\
\text { Mean }\end{array}$ \\
\hline $\begin{array}{l}\text { DRPM -1 level } \\
\text { wavelet Filter }\end{array}$ & 0.288 & 0.284 & 0.377 & 0.569 & 0.522 & 0.591 & 0.704 & 0.705 \\
\hline $\begin{array}{l}\text { DRPM - } 2 \text { level } \\
\text { wavelet filter }\end{array}$ & 0.668 & 0.631 & 0.690 & 0.697 & 0.500 & 0.506 & 0.788 & 0.790 \\
\hline $\begin{array}{l}\text { DRPM - } 3 \text { level } \\
\text { wavelet filter }\end{array}$ & 0.418 & 0.355 & 0.192 & 0.202 & 0.396 & 0.396 & 0.688 & 0.677 \\
\hline
\end{tabular}

Title Page

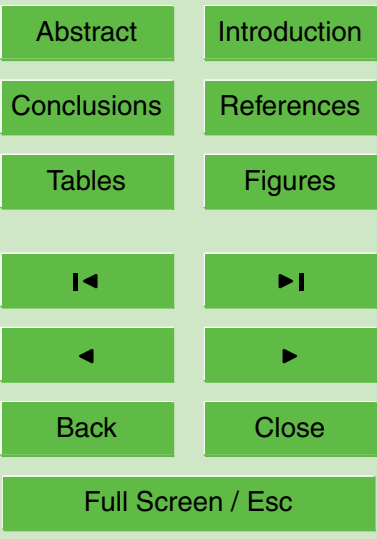

Print Version

Interactive Discussion 


\section{HESSD}

2, 543-568, 2005

\section{DRPM using a UDC}

S. Tantanee et al.

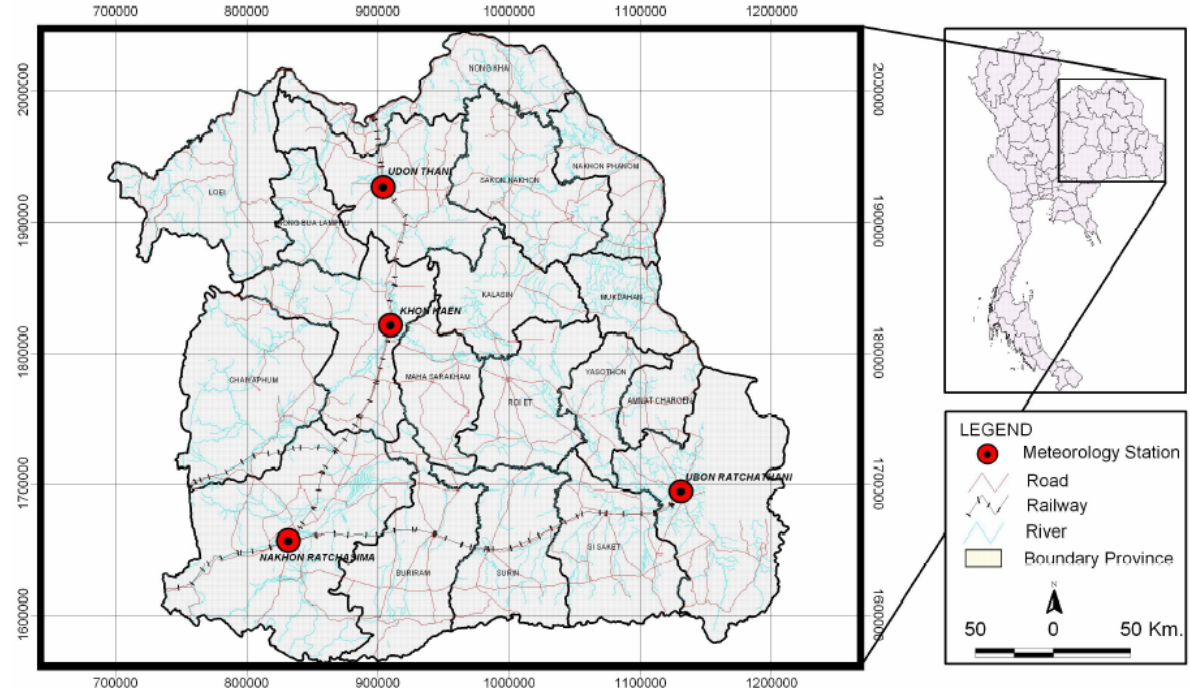

Title Page

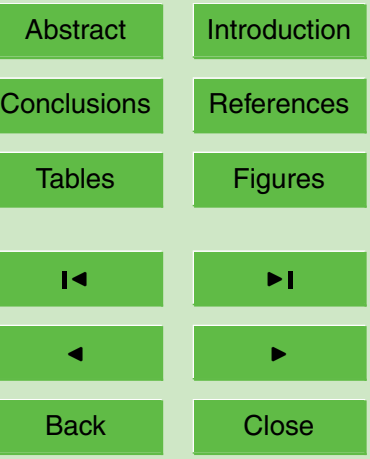

Full Screen / Esc

Fig. 1. Location of the 4 selected rainfall stations.

Print Version

Interactive Discussion

EGU 


\section{HESSD}

2, 543-568, 2005

\section{DRPM using a UDC}

S. Tantanee et al.

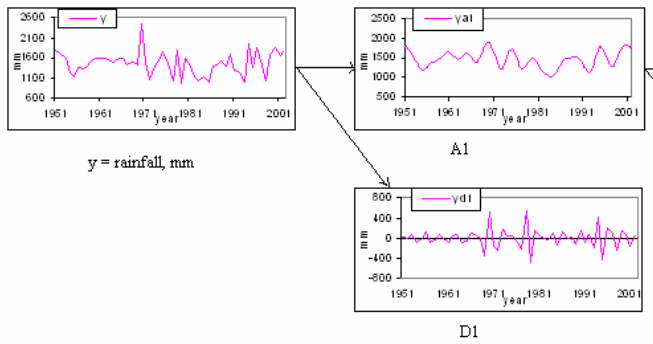

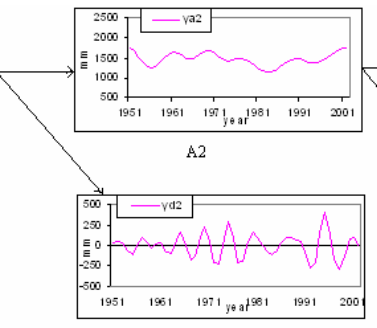

D2

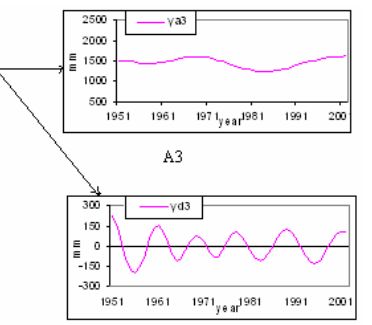

D3

Fig. 2. Rainfall series pass through 1-3 layer of wavelet filter (Udon Thani station).

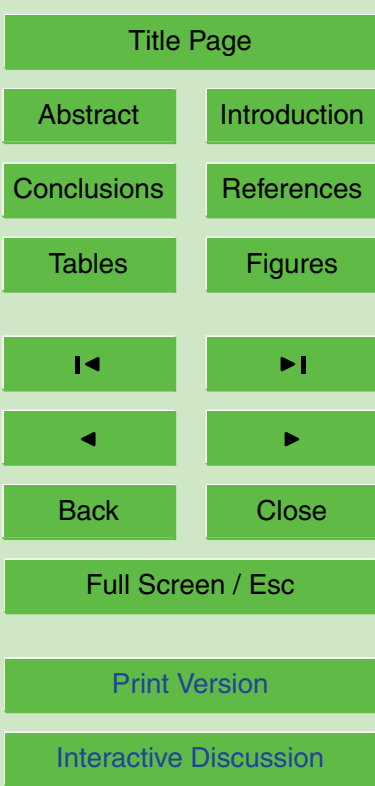

EGU 


\section{HESSD}

2, 543-568, 2005

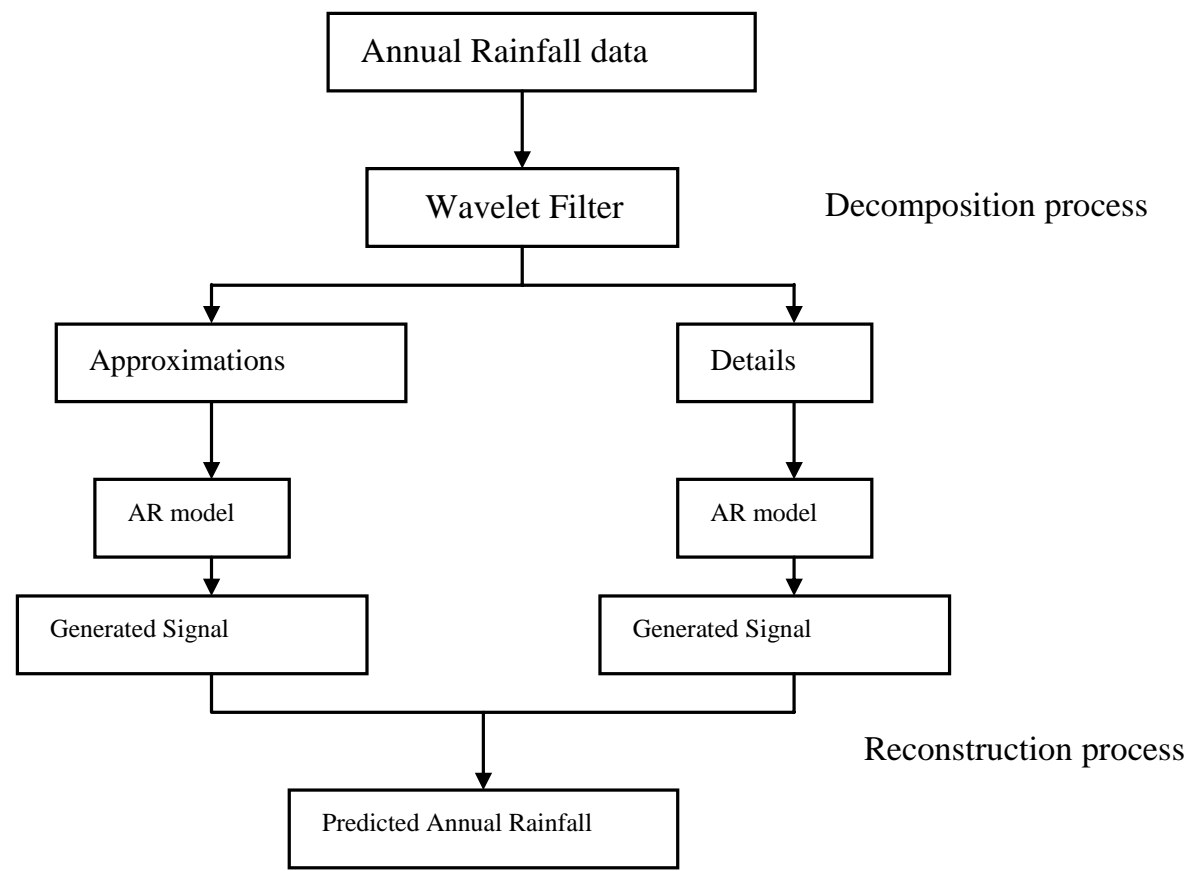

DRPM using a UDC

S. Tantanee et al.

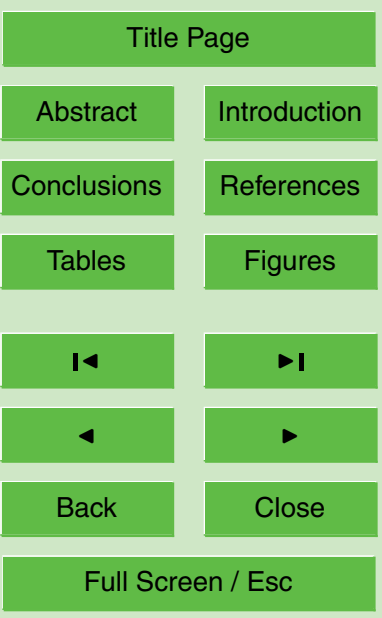

Print Version

Fig. 3. The process of coupling AR with wavelet filter for annual rainfall prediction.

Interactive Discussion

EGU 
2, 543-568, 2005

\section{DRPM using a UDC}
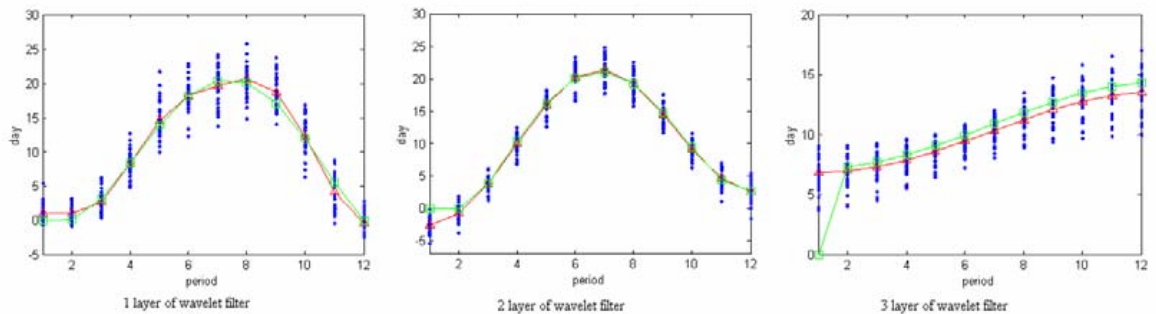

S. Tantanee et al.

Distribution of Approximations of mumber of rainy days
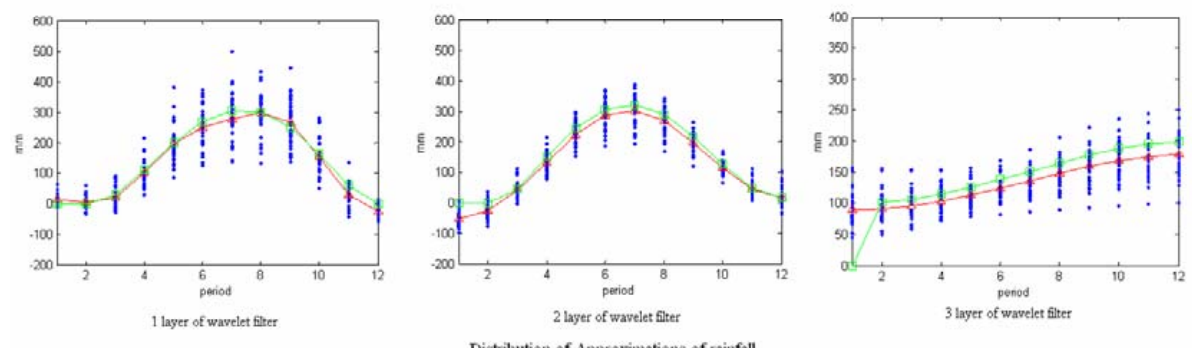

Title Page

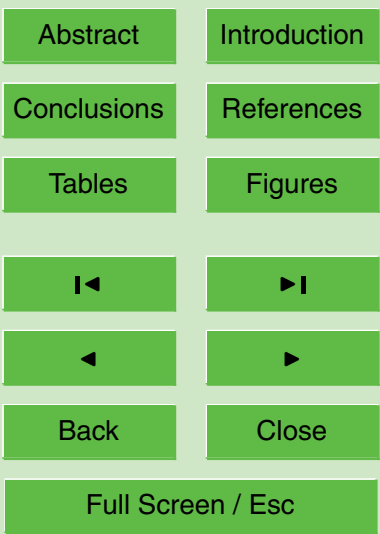

Fig. 4. Approximations distribution within a year of Ubon Ratchathani station (red line: mean value, green line: value from polynomial fitting curve).

Print Version

Interactive Discussion 


\section{HESSD}

2, 543-568, 2005

\section{DRPM using a UDC}
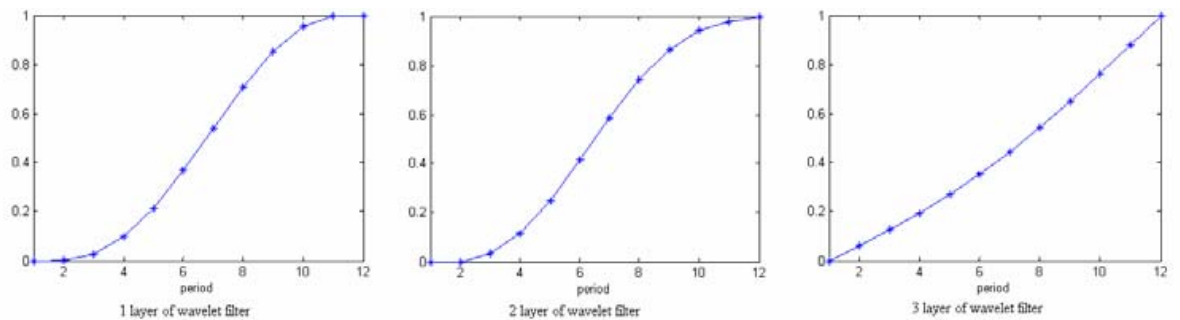

S. Tantanee et al.
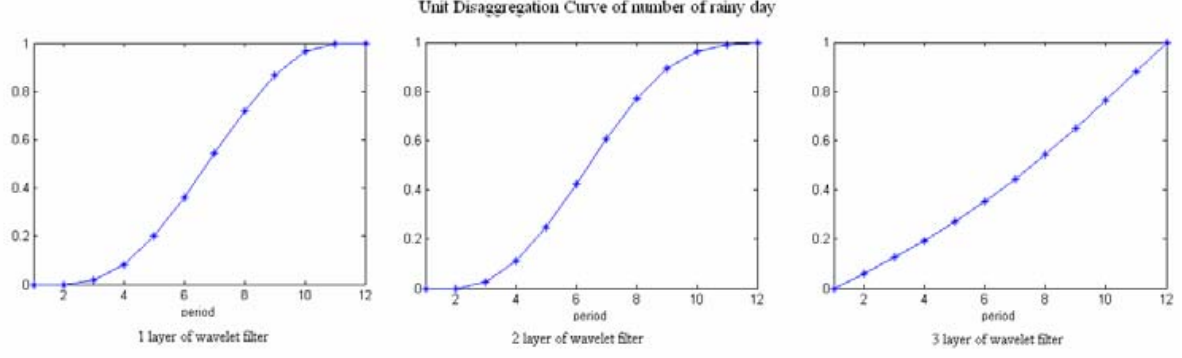

Unit Disageregation Curve of raimfal

Abstract

Conclusions

Tables

Title Page

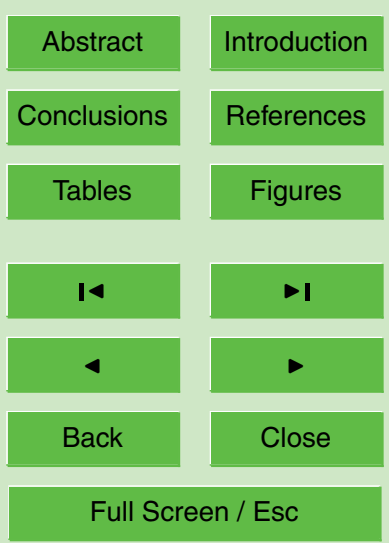

Fig. 5. Obtained Unit Distribution Curve from polynomial fitting curve of the number of rainy days and rainfall (Ubon Ratchathani station).

Print Version

Interactive Discussion 


\section{HESSD}

2, 543-568, 2005

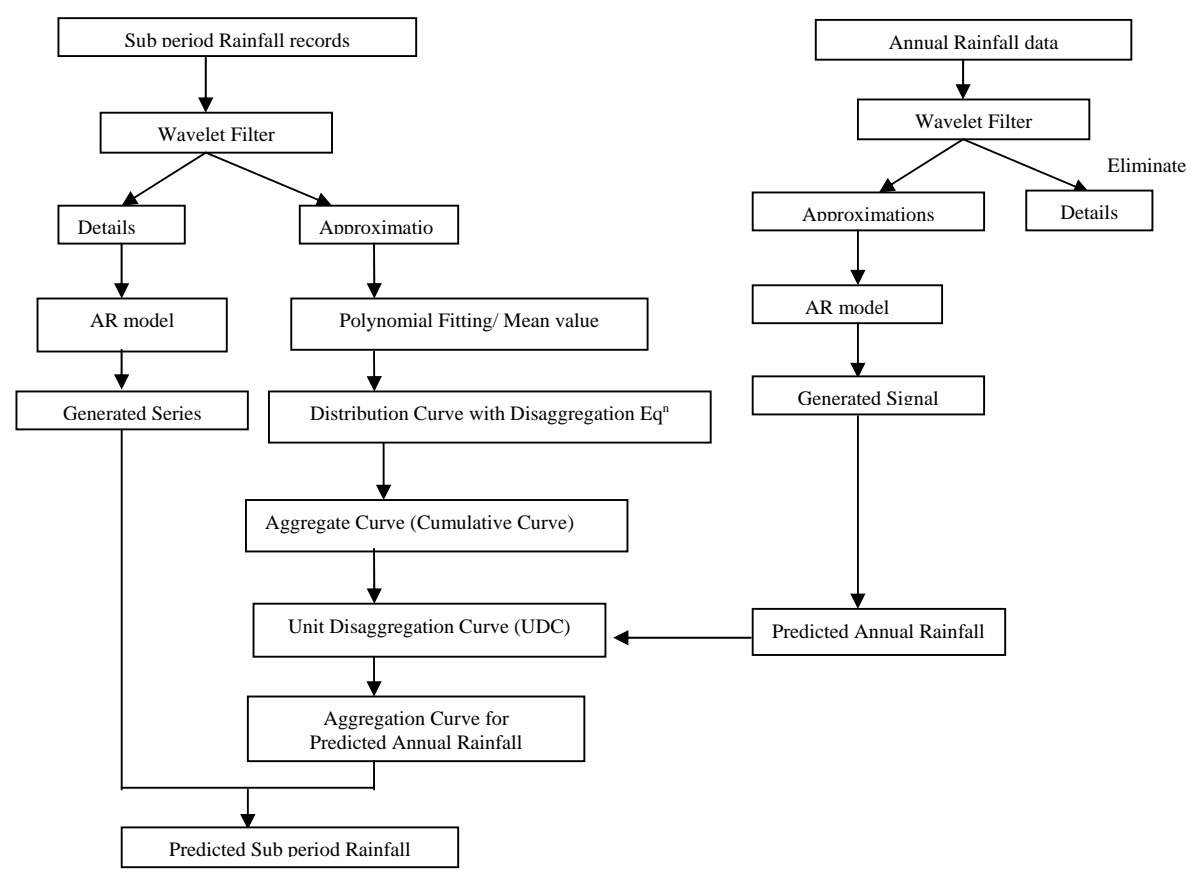

DRPM using a UDC

S. Tantanee et al.

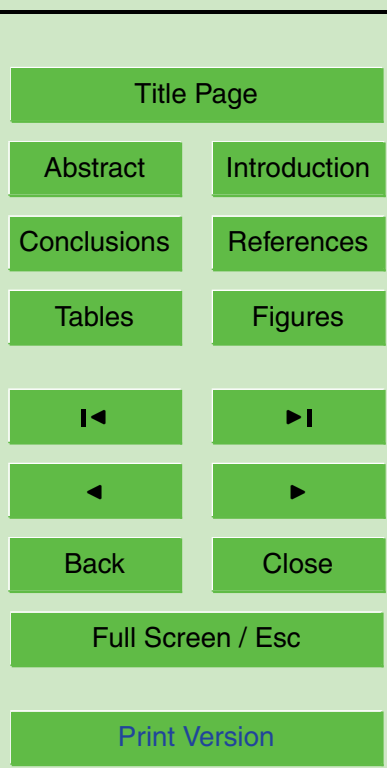

Fig. 6. DRPM model structure.

Interactive Discussion

EGU 


\section{DRPM using a UDC}

S. Tantanee et al.

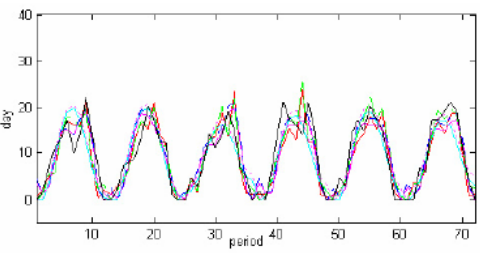

Thon Taen Stakion

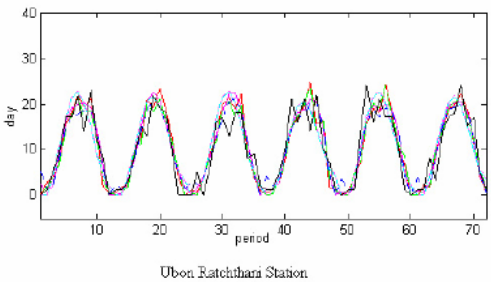

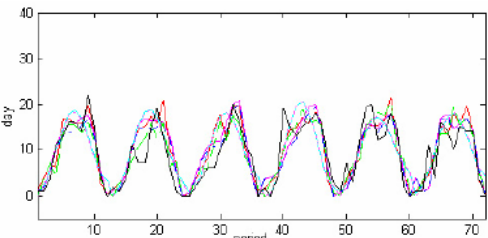

Nakhos Ratchasima Station

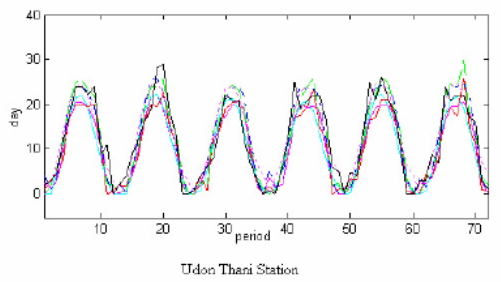

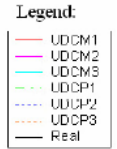

Fig. 7. The generated series of number of rainy days (1997-2002) by DRPM of 1-3 level of filter. UDCMx: process of $x$ level of wavelet filter and UDC from mean values curve. UDCPx: process of $x$ level of wavelet filter and UDC from Polynomials fitting curve. Real: historical records.

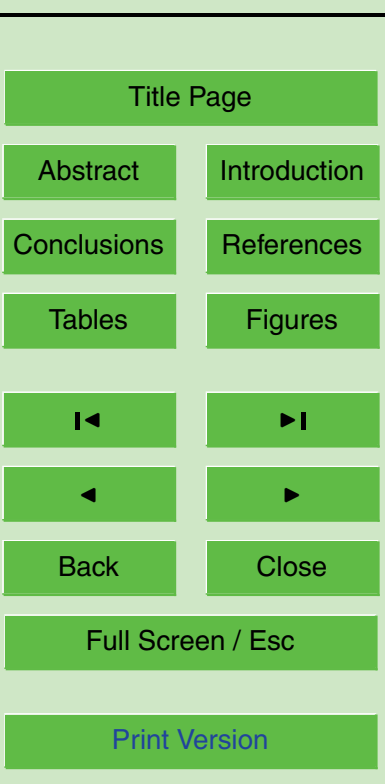

Interactive Discussion 
DRPM using a UDC

S. Tantanee et al.
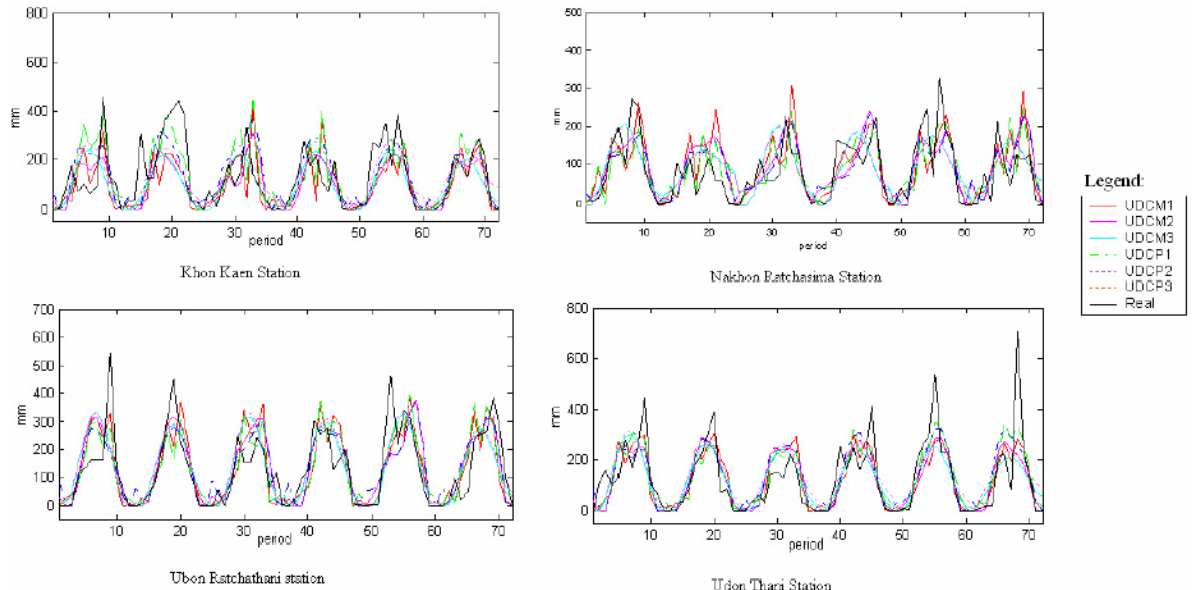

Title Page

Abstract Introduction

Conclusions

References

Tables

Figures

14

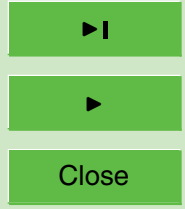

Back

Fig. 8. The generated series of rainfall (1997-2002) by DRPM of 1-3 level of filter. UDCMx: process of $x$ level of wavelet filter and UDC from mean values curve. UDCPx: process of $x$ level of wavelet filter and UDC from Polynomials. fitting curve. Real: historical records.

Full Screen / Esc

Print Version

Interactive Discussion 


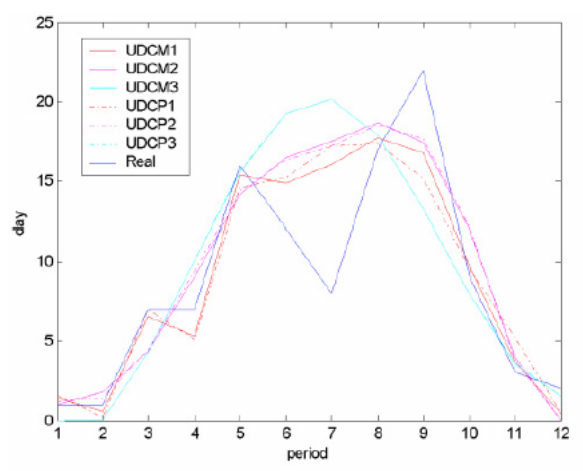

Khon Kaen Sation

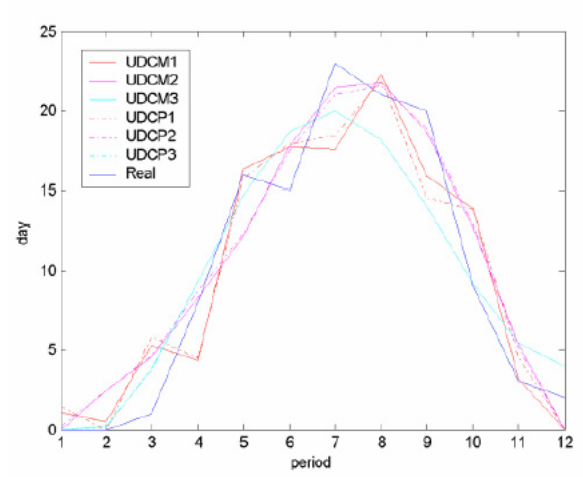

Ubon Ratchathani Station

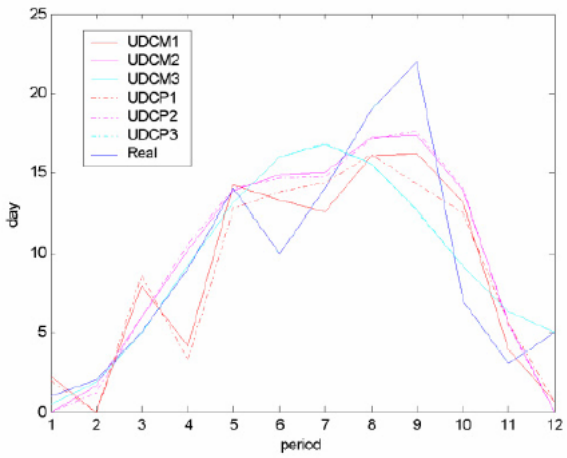

Nakhon Ratchasima Station

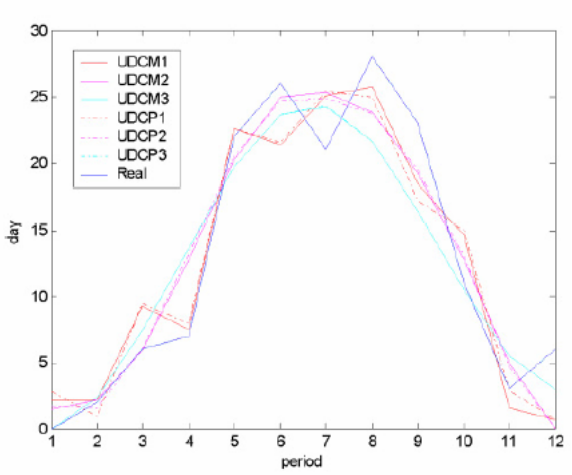

Udon Thani Station

\section{HESSD}

2, 543-568, 2005

DRPM using a UDC

S. Tantanee et al.

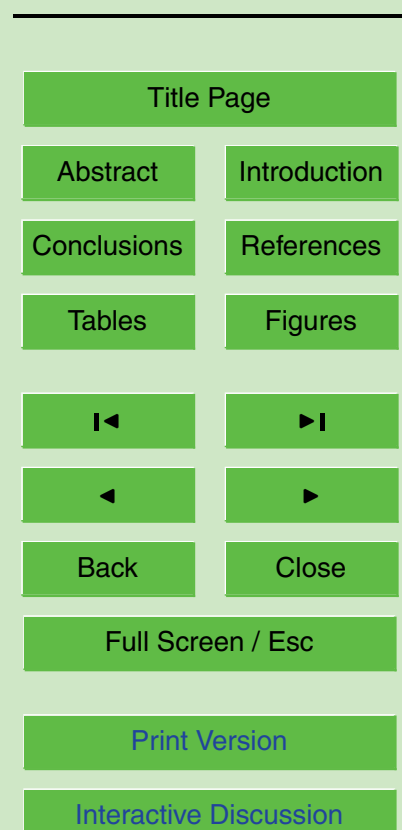

EGU

Fig. 9. The predicted number of rainy days in the year 2002 by DRPM of 1-3 level of filter. UDCMx : process of $x$ level of wavelet filter and UDC from mean values curve. UDCPx: process of $\mathrm{x}$ level of wavelet filter and UDC from Polynomials fitting curve. Real: historical records. 

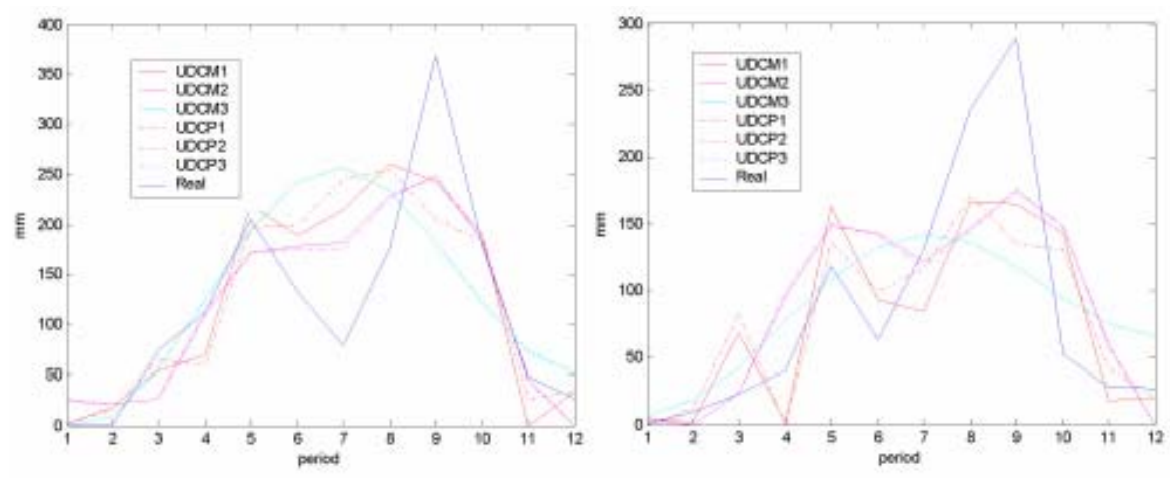

Khon Kaen station

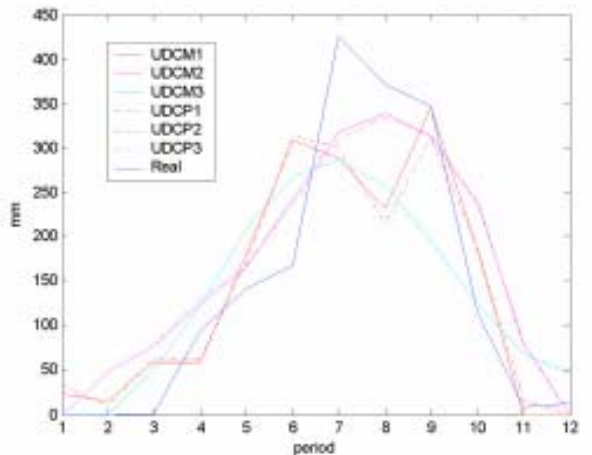

Ubon Ratchathani Station

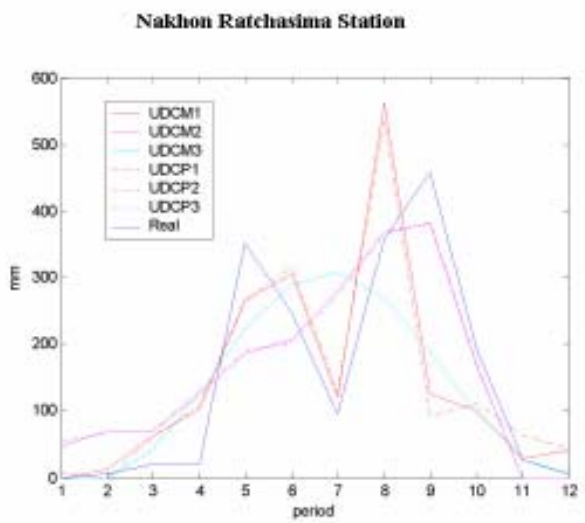

Uden Thani Station
HESSD

2, 543-568, 2005

DRPM using a UDC

S. Tantanee et al.

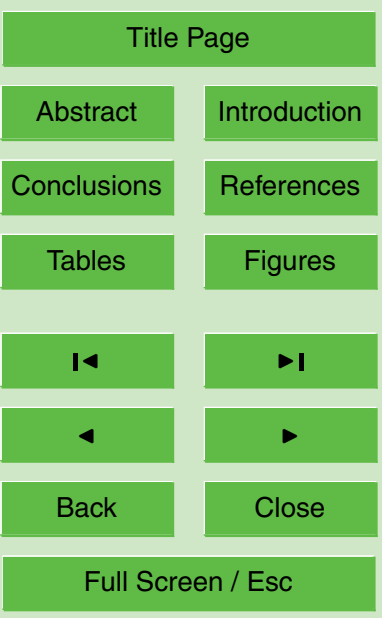

Print Version

Interactive Discussion

Fig. 10. TThe predicted number of rainfall in the year 2002 by DRPM of 1-3 level of filter. UDCMx: process of $x$ level of wavelet filter and UDC from mean values curve. UDCPx: process of $x$ level of wavelet filter and UDC from Polynomials fitting curve. Real: historical records. 